Барчі Беата

кандидат психологічних наук, старший викладач кафедри психології Мукачівського державного університету ORCID iD: 0000-0002-5923-7331.

DOI https://doi.org/10.35619/prap_rv.vi13.114

\title{
ПСИХОЛОГІЧНЕ ДОСЛІДЖЕННЯ ЕМОЦІЙНОГО СТАНУ БЕЗРОБІТНИХ ОСІБ
}

Анотація. Однією із найважливіших соціально-економічних проблем сьогодення $\epsilon$ безробіття. У статті представлено аналіз досліджень вітчизняних та зарубіжних учених до проблеми безробіття людей та з'ясовано, щу дана проблема потребує розв'язання на загальнодержавному рівні з впровадженням організачійних заходів і системи психологічного забезпечення. Визначено, що джерелами формування емочійного стану безробітних $\epsilon$ деформачія потреб, втрата звичної структури часу та звичного порядку дій. Доведено, щчо емоційний стан людини в ситуаиії безробіття розвивається залежно від етапу розвитку даної ситуації, тривалості безробіття, характеристик особистості та низки показників середовища безробітного. Емоційний стан безробітного, за певних умов, може стати стресовим або кризовим. Наслідки переживання ситуаџії безробіття проявляються як під час даної ситуації, так і в подальшому житті людини, яка пережила безробіття. Виділено прояви безробітних внутрішнього переживання своєї неспроможності забезпечити гідне існування членів своєї сім'ї. Зазначено, щуо домінанта негативізму призводить до астенічних психічних станів, нервово психічних розладів $i$ навіть до виникнення чи загострення соматичних захворювань. Ситуачія безробіття як фактор формування конкурентоспроможності відрізнясться неоднозначністю впливу $і$ може, в залежності від різноманітних показників, стати як обмежуючим, так i позитивним фактором. Так, водночас, для певної частини осіб, які опинилися в такій скрутній життєвій ситуачії втрата роботи означає підвищення активності, мобілізації своєї життєвої енергії. Визначено, щуо частина безробітних потребує психологічної реабілітації ту супроводу. Отримані результати дають можливість в подальшому розробити і організувати роботу з формування у безробітних готовності до подолання негативних емоційних станів у формі тренінгів, семінарів, консультачій.

Ключові слова: безробіття, психологічний аналіз, об'єктивні детермінанти, суб' єктивні детермінанти, негативні впливи, емочійні стани.

Постановка проблеми. Економічна криза у Україні призвела до збільшення кількості безробітних громадян. Коли людина втрачає роботу, то вона втрачає не тільки засоби існування, а й цілий комплекс важливих зав'язків із соціальною реальністю, що може призводити до появи негативних емоційних станів. Безробіття є проблемою, що справляє прямий, потужний вплив на кожну людину і має руйнівну силу. Ї̈̈ жертвами стають мільйони працівників, їхні сім’ї, цілі міські та сільські райони. Дослідниками відмічається, що безробіття негативно позначається на середній тривалості життя, стані здоров'я та рівні смертності, пристрасті до алкоголю та інших психоактивних речовин. Коли людина опиняється у стані безробіття, то скорочуються не тільки дохід сім’ї, а й втрачається самоповага людини, виникають депресії і спостерігається відчуття безнадії в завтрашньому 
дні. У зв’язку 3 цим, особливо актуальним стає вивчення сучасних процесів, що відбуваються на ринку праці, а також наслідків зростання безробіття i особливостей соціальної та соціально-педагогічної роботи 3 безробітними громадянами. Проблемою нашого дослідження ми вбачаємо виявлення психічних наслідків безробіття та певних можливостей їх подолання. Готовність до професійного перенавчання та подальшого працевлаштування значною мірою залежить від емоційного стану безробітного, його здатності до усвідомленого почуття та психічного стану, дослідження чого набуває все більшого значення.

Аналіз останніх досліджень 3 проблеми. Теоретичним підгрунтям у дослідженні проблеми безробіття можуть слугувати надбання світової економічної науки. Основні аспекти безробіття, причини його виникнення та шляхи регулювання досліджували Апельбаун (2012), Діенер (2003) Кругер, Андреас (2012) та інші. Серед українських вчених, які займалися проблемою безробіття можна виокремити роботи Гладун (2012), Максименка, Мазаракі, Кулаковської, Кулаковського (2012), Грішнової (2011), Жиляк (2015), Іваницької (2015), Рудюка (2011), Марусинець, Барчі (2018) та інші. Безробіття - це соціальноекономічне явище, в результаті якого частина працездатного населення не може знайти роботи, стає відносно надлишковою, поповнюючи резерв робочої сили, тобто це перевищення пропозиції робочої сили над попитом на неї (Грішнова, 2011). Безробітні у визначенні Міжнародної організації праці - $є$ особи у віці 15-70 років (як зареєстровані, так і незареєстровані в державній службі зайнятості), які одночасно задовольняють три умови: не мають роботи (прибуткового заняття), шукають роботу або намагаються організувати власну справу, готові приступити до роботи впродовж двох наступних тижнів (Червінська, 2010). Отже, аналіз останніх досліджень і публікацій, в яких започатковано розв'язання цієї проблеми показав, що нині вченими певною мірою з'ясовано економічні детермінанти формування безробіття (Машика, 2013). У наукових публікаціях акцент робиться на окремі детермінанти і прояви впливів безробіття на рівні самовизначення, мотивацію, психічні стани (Фесенко, 2014). Це в свою чергу є підгрунтям для комплексного підходу дослідження проблеми впливу безробіття на різні структурні рівні особистості, а також емоційні стани переживання даної ситуації. Проблема безробіття має далекосяжні наслідки

Мета статті.. Отже, метою даного дослідження є вивчення особливостей прояву емоційно-вольових станів безробітних та можливостей подолання труднощів.

Виклад основного матеріалу дослідження. Безробітні поряд із зайнятими формують робочу силу нашої країни. Безробіття - це соціально-економічне явище, при якій значна частина робочої сили, економічно активного населення, не зайнята у виробництві. Без сумніву, у тих, хто не може знайти собі роботу існують психологічні проблеми; спостерігаються значні зміни в оцінці своєї компетентності, власної активності, рівень задоволеності життям.

Слід розрізняти два основних типи безробіття: природне й вимушене. Природне безробіття набуває форми добровільного, фрикційного, інституціонального. Добровільне безробіття - робітники відмовляються працювати за пропоновану їм зарплату або з тих чи інших причин не хочуть шукати роботу. Фрикційне безробіття - характерним $є$ стан пошуку або очікування роботи в найближчому майбутньому. Інституціональне безробіття викликане небажанням деякої частини працездатного населення працювати у зв'язку з гарантією виплати державою допомоги по безробіттю. Вимушене безробіття - коли людина в працездатному віці не працює з незалежних від неї причин (не може знайти роботу, бо немає вільних робочих місць) (Покрищук, 2005). 
Держава надає додаткові гарантії громадянам, які особливо потребують соціального захисту й відчувають труднощі в пошуку роботи. Розробляються і реалізуються програми 3 метою сприяння зайнятості населення. Створюються додаткові робочі місця й спеціалізовані організації. Надаються послуги з професійної орієнтації, а також можливість навчання за спеціальними програмами. Недостатня експериментальна вивченість негативних психічних станів безробітних визначає важливість та актуальність нашого проведеного дослідження. Під час дослідження для отримання більш об'єктивних даних про реальні психічні стани безробітних проводилось комплексне обстеження 100 осіб у Мукачівському міському центрі зайнятості за допомогою особистісних опитувальників. За віком обстеження безробітні розподілялися таким чином: - до 25 років - 25,3\%; - від 26 до 45 років - 70,1\%; - понад 45 років - 4,6\%. Проведене дослідження у Мукачівському міському центрі зайнятості виявило наявність двох видів агресивності у безробітних: спонтанної та реактивної. Високі показники першого виду агресивності (42,1\% осіб) свідчать про підвищений рівень психопатизації осіб. Це створює передумови для їх імпульсивної поведінки. Насторожують дані про реактивну агресивність безробітних (51,8\% осіб), як реакції на обставини. Високий рівень агресивності було виявлено у 21,7\% обстежених осіб (від 46 до 55 балів), а занадто високий рівень - у 37,9\% безробітних (від 56 до 100 балів). При цьому помітна прогресуюча тенденція до росту кількості співробітників із занадто високим рівнем агресивності залежно від періоду їх перебування у стані безробітного.

За допомогою опитувальник FPI вивчалась стійкість безробітних до стресу, їхня схильність до стресового реагування на звичайні життєві ситуації. Так, 29,1\% від кількості обстежених осіб мають слабку захищеність до впливу стрес- факторів звичайних життєвих ситуацій. Вони невпевнені в малоактивні, собі, неініціативні. Їхній настрій переважно не стійкий з рисами тривожності. 53,9\% мають середню захищеність до впливу стрес-факторів життєвих ситуацій. У непередбачених ситуаціях проявляють невпевненість, хитання, займають позицію очікування. І лише 19,1\% від загальної кількості обстежених безробітних мають добру захищеність до впливу стрес-факторів життєвих ситуацій, яка грунтується на оптимістичності, активності та впевненості в собі. 52,1\% відчувають труднощі в соціальних контактах. Ці особи схильні до стресового реагування на життєві ситуації, проте це реагування відображається у пасивно оборонному типі. Їм властива обережність, наявність тривожності, скутості, невпевненості, ніяковості. вони. Переважає мотивація на уникнення невдач. Такі особи проявляють слабку готовність до дії. Прагнуть приховати від оточення дефекти свого характеру. За допомогою опитувальника FPI було виявлено, що 50,2\% обстежених осіб мають недостатню стабільність емоційного стану, часто у них мають місце коливання настрою. В критичних або конфліктних ситуаціях їм важко володіти собою й витісняти фактори, які викликають тривогу. У той час $49,8 \%$ осіб мали нестійкий емоційний стан, який проявляється в частих коливаннях настрою, підвищеній збудливості, дратівливості, недостатній саморегуляції. Вони схильні до афективного реагування та істеричних реакцій в умовах стресу. У них спостерігаються труднощі в міжособистісних контактах. Можуть проявляти демонстративність поведінки, прагнення заперечувати труднощі соціальної адаптації, високочутливі до впливів середовища. Ігнорують негативні сигнали з боку оточення.

Наведені дані спонукають до організації та проведення цілеспрямованої та систематичної індивідуальної та групової роботи психологів соціальної служби у формуванні у безробітних психологічної стійкості до емоційного стресу. Використання шкал депресії опитувальників MMPI та FPI свідчить, що 42,1\% обстежених безробітних 
мають ознаки, характерні для психопатологічного депресивного синдрому в емоційному стані, в поведінці, в ставленні до себе. Вони проявляють схильність до депресивних реакцій, болісного переживання невдач. Використання особистісних опитувальників стосовно безробітних підтвердило домінування у них найбільш поширених 3-поміж інших таких негативних станів вольових, а саме: апатія, невпевненість, пасивність та афективних: агресія, депресія, емоційний стрес, психічна напруга, тривога. Все це викликається специфічними умовами життєдіяльності. Спостерігається поступове «переплавлення» негативних станів у властивості особистості. Спостерігалось, із ростом стажу безробіття агресія, як стан, стимулює розвиток особистісної агресивності стосовно інших людей, стан реактивної тривоги переходить в особистісну тривожність, а стан пасивності формує пасивність як рису характеру, а згодом і життєву позицію особистості.

В цілому накопичення негативно забарвлених психічних станів призводить до виникнення та закріплення в структурі характеру рис, які знижують адаптивні можливості особистості та ті, які руйнують ii психічне здоров'я. Причина того, що безробіття сприймається самим суб'єктом і його оточенням як найгостріша стресова ситуація, полягає в тому глибинному зв'язку, який існує між особистим самоусвідомленням і трудовою діяльністю. Робота є одним з головних чинників, що визначають внутрішнє самопочуття людини. У зв'язку з цим виникає нагальна необхідність у проведенні серед безробітних профілактичної та корекційної роботи, спрямованої на зняття негативних станів, пом'якшення дії їх руйнуючих факторів та збереження психічного здоров'я безробітних.

Висновки і перспективи подальших розвідок. Втрата професійної діяльності в працездатному віці сприймається більшістю людей як крах усього їхнього життєвого устрою. Підсумовуючи вищесказане, можна констатувати, що серед наслідків безробіття відмічається різке зниження самооцінки та збільшення негативних емоційних станів, у багатьох випадках виникає депресивний синдром із тенденціями до суїциду. Стрес, перенесений у період безробіття, може спричинити скорочення тривалості життя людини. Перспективою подальшого дослідження $\epsilon$ розробка ефективних програм тренінгів задля забезпечення зайнятості, зниження емоційного негативного фону та розв'язання проблем членів сім’ї безробітного, вдосконалення роботи психологів консультантів служби зайнятості, для здійснення комплексного регулювання питань психічної сфери безробітних.

\section{СПИСОК ПОСИЛАНЬ}

Гладун, О. М. (2012). Методологічні аспекти дослідження взаємозв’язку між безробіттям та злочинністю на районному рівні. Вісник Хмельницького національного університету, $1,3,258-260$.

Грішнова, О. А. (2011). Економіка праџฺі та соиіально-трудові відносини (5-те вид.). Київ: Знання.

Жиляк, Н. В. (2015). Деякі аспекти самовизначення безробітних у процесі профпереорієнтації. Актуальні проблеми розвитку організаційної та економічної психології в Україні, 86-87.

Іваницька, С. Б. (2015). Проблема безробіття в Україні. Ефективна економіка, 9, 34-38.

Максименко, С. Д., Мазаракі, А. А., Кулаковська, Л. П., Кулаковський, Т. Ю. (2012). Підприємництво: психологічні, організаційні та економічні аспекти. Київ: Київський національний торговельно-економічний університет.

Марусинець, М. М., Барчі, Б. В. (2018). Стратегії поведінкових дій безробітних: статевий i віковий аспект дослідження. Український психологічний журнал, 3 (9), 107-121. 
Машика, Ю. В. (2013). Проблеми та рівень безробіття в Україні та країнах Європейського союзу. Науковий вісник НЛТУ України, 23, 16, 260-264.

Покрищук, В. (2005). Мотиваційна поведінка безробітної молоді в Україні. Україна: аспекти nраuі, 8, 7-12.

Рудюк, О. В. (2011). Личностно-смысловые детерминанты пережсивания безработными профессиональных кризисов. (Автореф. дис. канд. психол. наук). Институт психологии им. Г. С. Костюка НАПН Украины. Киев.

Фесенко, А. М. (2014). Невирішеність проблеми працевлаштування як фактор соціального відчуження молоді. Педагогіка та соиіальна робота, 6, 51-56.

Appelbaum, B. (2012). The Enduring Consequences of Unemployment. New York Times, March 28.

Diener, Ed., Shigehirok, O., \& Richard, E. L. (2003). Personality, Culture, and Subjective WellBeing: Emotional and Cognitive Evaluations of Life. Annual Review of Psychology, 54, 403-425.

Krueger, A. B., \& Mueller, A. I. (2012). Time Use, Emotional Well-Being, and Unemployment: Evidence from Longitudinal Data. American Economic Review, 102(3), 594-599.

\section{REFERENCES}

Gladun, O. M. (2012). Metodologichni aspekti doslidzhennya vzaєmozv’yazku mizh bezrobittyam ta zlochinnistyu na rayonnomu rivni [Methodological aspects of the study of the relationship between unemployment and crime at the district level]. Visnik Khmelnitskogo natsionalnogo universitetu, 1, 3, 258-260. [in Ukrainian].

Grishnova, O. A. (2011). Ekonomika pratsi ta sotsialno-trudovi vidnosini [Labor economics and social-labor relations] (5-te vid.). Kyiv: Znannya. [in Ukrainian].

Zhilyak, N. V. (2015). Deyaki aspekti samoviznachennya bezrobitnikh u protsesi profpereorientatsii [Some aspects of self-determination of the unemployed in the process of professional reorientation]. Aktualni problemi rozvitku organizatsiynoï ta ekonomichnoi psikhologiï $v$ Ukraini , 86-87. [in Ukrainian].

Ivanitska, S. B. (2015). Problema bezrobittya v Ukraini [The problem of unemployment in Ukraine. An efficient economy]. Efektivna ekonomika, 9, 34-38. [in Ukrainian].

Maksimenko, S. D., Mazaraki, A. A., Kulakovska, L. P., \& Kulakovskiy, T. Yu. (2012). Pidpricmnitstvo: psikhologichni. organizatsiyni ta ekonomichni aspekti [Entrepreneurship: Psychological, Organizational and Economic Aspects]. Kyiv: Kyivs'kyy natsional'nyy torhovel'no-ekonomichnyy universytet. [in Ukrainian].

Marusinets, M. M., \& Barchi, B. V. (2018). Strategii povedinkovikh diy bezrobitnikh: stateviy i vikoviy aspekt doslidzhennya [Behavioral strategies for the unemployed: the gender and age aspects of research]. Ukrainskiy psikhologichniy zhurnal, 3 (9), 107-121. [in Ukrainian].

Mashika, Yu. V. (2013). Problemi ta riven bezrobittya v Ukraini ta krainakh Evropeyskogo soyuzu [Problems and unemployment in Ukraine and the European Union]. Naukoviy visnik NLTU Ukraini, 23, 16, 260-264. [in Ukrainian].

Pokrishchuk, V. (2005). Motivatsiyna povedinka bezrobitnoi molodi v Ukraini [Motivational behavior of unemployed youth in Ukraine]. Ukraina: aspekti pratsi, 8, 7-12. [in Ukrainian].

Rudyuk, O. V. (2011). Lichnostno-smyslovyye determinanty perezhivaniya bezrabotnymi professionalnykh krizisov [Personality-semantic determinants of experience of unemployed occupational crises]. (Avtoref. dis. kand. psikhol. nauk). Institute of Psychology G. S. Kostyuk NAPN of Ukraine. Kyiv. [in Russian].

Fesenko, A. M. (2014). Nevirishenist problemi pratsevlashtuvannya yak faktor sotsialnogo vidchuzhennya molodi [Unresolved problem of employment as a factor of social exclusion of young people]. Pedagogika ta sotsialna robota, 6, 51-56. [in Ukrainian]. 
Appelbaum, B. (2012). The Enduring Consequences of Unemployment. New York Times, March, 28. [in English].

Diener, Ed., Shigehiro, O., \& Richard, E. L. (2003). Personality, Culture, and Subjective WellBeing: Emotional and Cognitive Evaluations of Life. Annual Review of Psychology, 54, 403-425. [in English].

Krueger, A. B., \& Mueller, A. I. (2012). Time Use, Emotional Well-Being, and Unemployment: Evidence from Longitudinal Data. American Economic Review, 102 (3), 594-599. [in English].

\title{
PSYCHOLOGICAL RESEARCH THE EMOTIONAL STATE OF UNEMPLOYED
}

Beata Barchi

candidate of Psychological Sciences, Senior Lecturer of Psychology chair

Mukachevo State University ORCID iD: 0000-0002-5923-7331.

DOI https://doi.org/10.35619/prap_rv.vi13.114:

\begin{abstract}
One of the most important social and economic problems of today is unemployment. This article presents the study analysis of native and foreign scientists on the problem of unemployment. It has been found that this problem needs to be solved at the state level with the introduction of organizational measures and psychological support. It has been determined that the sources of formation of the emotional state of the unemployed are deformation of needs, loss of the usual structure of time and habitual order of action. It has been proved that the emotional state of a person in a situation of unemployment develops depending on the stage of development of the situation, the duration of unemployment, personality characteristics and a number of indicators of the environment of the unemployed. The emotional state of the unemployed, under certain conditions, can become stressful or crisis. The consequences of experiencing the unemployment situation are manifested both during this situation and in the subsequent life of the person who survived the unemployment. Emphasis has been placed on the unemployed to experience the inward experience of their inability to secure a decent existence for their family members. It has been noted that the dominant of negativism leads to asthenic mental states, neuropsychiatric disorders and even to the occurrence or exacerbation of somatic diseases. The unemployment situation as a factor in the formation of competitiveness differs ambiguity of influence and can, depending on various indicators, become both limiting and a positive factor. So, at the same time, for some of the people who find themselves in such a difficult life situation, the loss of work means increased activity, mobilization of their vital energy. It is determined that some of the unemployed need psychological rehabilitation of that support. The obtained results give an opportunity to further researches to develop and organize work on forming in the unemployed readiness to overcome negative emotional states in the form of trainings, seminars, consultations.
\end{abstract}

Keywords: unemployment, psychological analysis, objective determinants, subjective determinants, negative influences, emotional states. 